\title{
READING MATERIAL DEVELOPMENT OF DESCRIPTIVE TEXT BASED ON PROBLEM BASED LEARNING GRADE $X$ STUDENTS OF ELECTRICAL ENGINEERING AT SMK SINAR HUSNI MEDAN
}

\author{
AN ARTICLE \\ Submitted in Partial Fulfillment of the Requirements \\ for the Degree of SarjanaPendidikan
}

By:

NISFU SARI

Registration Number: 2133321009

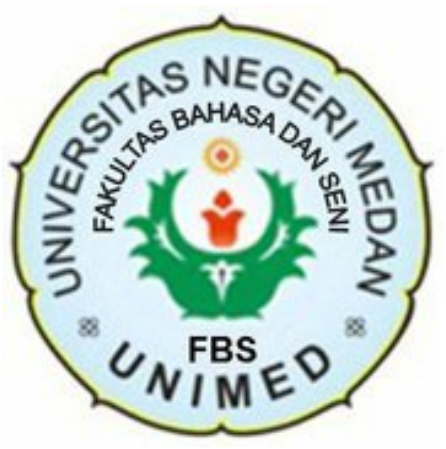

ENGLISH AND LITERATURE DEPARTMENT

FACULTY OF LANGUAGES AND ARTS

STATE UNIVERSITY OF MEDAN

2018 


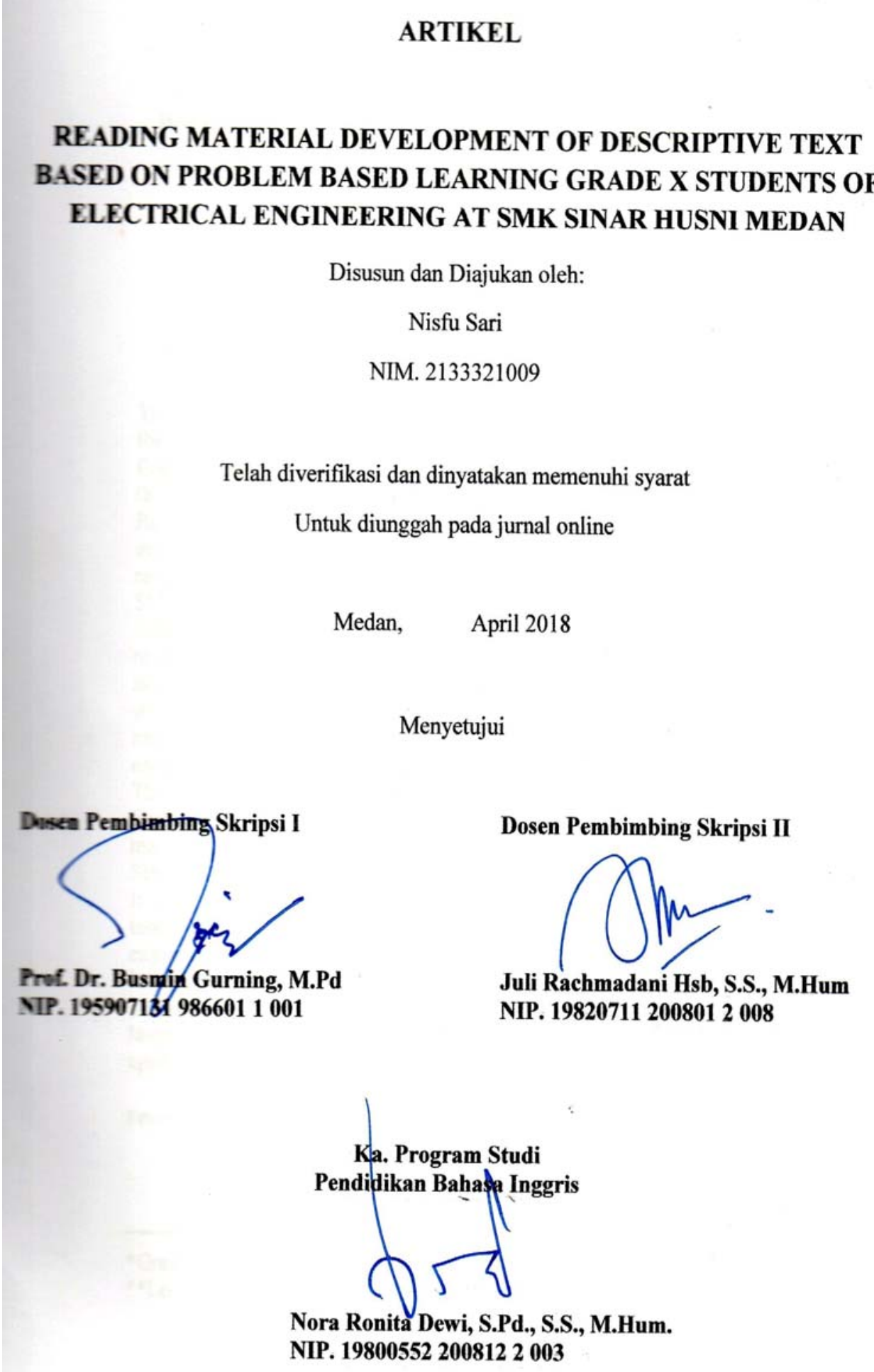




\title{
READING MATERIAL DEVELOPMENT OF DESCRIPTIVE TEXT BASED ON PROBLEM BASED LEARNING GRADE $X$ STUDENTS OF ELECTRICAL ENGINEERING AT SMK SINAR HUSNI MEDAN
}

\author{
*Nisfu Sari \\ ** Busmin Gurning \\ ** Juli Rachmadani Hasibuan
}

\begin{abstract}
The aims of this research were: (1) to find out the suitable the reading materials for grade eight students of SMP N 1 Kotapinang, (2) to find out how to design English reading materials based on problem based learning which is suitable to the needs of students of SMK Sinar Husni Medan. The research was conducted by Research and Development ( $\mathrm{R}$ \& $\mathrm{D}$ ) design through six stages; gathering information and data,analyzing data, designing materials, validating by experts, revising, and final product. The subject of this research was class $\mathrm{X}$ students of SMK Sinar Husni Medan consisting of 38 students. The instrumentations for collecting the data were questionnaire and interview. After, anlyzing the data, the researcher got the students' needs. The data were gathered by administering interview and distributing the questionnaire to 38 students to get the students'needs. The interview and questionnaire results proved that the students needs English reading materials which cointain English relating to their daily life environment. Thus, developing English reading mateials were descriptive text. The products have been validated by experts. The average scores are 5,17 from English Lecturer and 4,68 from English Teacher. It means the developing materials categorized as relevant or appropriate for Grade X Students of SMK Sinar Husni Medan. This research developed Problem Based Learning materials. It covers reading skill and consists of introduction, main lesson and reinforcement tasks. The input was in the form of written texts, vocabulary list and grammar explanation. The students were encouraged to do discussion and involve in active investigation to solve and do tasks. Most of the tasks are done in a small group discussion and in pairs. Based on the results of materials evaluation, the content, language, presentation and graphic of the developed materials are considered appropriate.
\end{abstract}

Keywords : Research and Development ( $R$ \& D, Problem Based Learning ,Descriptive Text

*Graduate Status

** Lecturer Status 


\section{INTRODUCTION}

\section{Background of the Study}

Reading is one of crucial English skills in language learning besides listening, writing, and speaking. Reading ability affects the other skills ability. There are some definitions of reading. Moreillon (2007: 10) states that reading can be simply defined as making meaning from print and from visual information. However, it is not as simple as what imagine. Reading is an active process that requires a great deal of practice and skill. It is a complex task which seems to go on inside people's heads. In order to be readers, learners must take their ability to pronounce words and to "read" pictures and then make the words and images mean something.

However, there are still many students who do not realize the importance of reading to support their life into a better direction. UNESCO (2012) reports that index of reading ability of Indonesian students reach in 0,001 . It means that out of one-thousand-Indonesian-students, there is only one who has reading ability. In line with the description above, Indonesian student must be able to have the reading skill to decrease the phenomenon. This must be instilled to Indonesian students early, that is Junior High School. Dealing with the terms of Junior High School as a continuation after primary school, the students still get the material related to basic education as well. The materials used also must suitable with the students' need, specifically for reading materials as one of the most important teaching materials to sharpen the reading skill. 
Unfortunately, English is like simply as complementary subject. Teacher does not give any directions to comprehend the words in the text. In every English Subject, the student just answer the questions in their English textbook in which the most of materials are not appropriate with the syllabus.

In the syllabus, students must respond to the meaning and rhetorical stages of a simple short essay accurately, and fluently relating to the surrounding environment in the form of descriptive text (based competence 5.3 of KTSP). The fact is the students learn the unsuitable text with the based competence which is about environment. The phenomenon is also supported by the preliminary data that points out the students' weakness in comprehending the text in their book.

Based on the preliminary observation in SMK Sinar Husni Medan it was found that 144 students have lower scores than 75 on their reading comprehensions. The Minimum Mastery Learning (MML) is 75, 144 students have not got the MML which its percentage is $58.3 \%$, 55 students got score more than MML which its percentage is $22.3 \%$ and 48 students got score 75 which its percentage is $19.4 \%$. It also can be seen that only 103 students from 247 students who passed the individual MML score.

From the preliminary data above, most of students do not master English lesson which they have in educational process, especially for reading materials. This evidence is a phenomenon of unsuccessful goal of education. Actually, there are some various factors influencing this unsuccessful goal of education; such as: unsuitable English reading materials, teaching method or strategy, 
student's low motivation, lack of vocabulary etc. The book which they use is English in Focus for Grade X Vocational School (written by Artom Wardiman) which is published by Kementrian Pendidikan dan Kebudayaan Republik Indonesia in the middle of 2014. The teacher usually teach their students by using available textbooks. Textbooks are a source of teaching materials which are widely used in teaching and learning process. It is the conventional source of learning for students. However, it is still quite capable of giving a good contribution to the teaching and learning process. Some of learning materials cannot be taught without the aid of textbooks.

The teacher also added that the lack of vocabulary is still shown by the students of this school in comprehending the words, even a basic word such as chalk, cupboard, board marker and eraser. They also have not been able to pronounce the basic word well. This reality shows that the student's vocabulary mastery in learning English is still low. The students also need to increase their ability of mastering vocabulary to support their skill in English Reading Material.

As someone who knows well what students need in learning process, the teacher has a right to take a decision about teaching materials (agree with the syllabus) which will be presented to the students, teaching methods in the classroom, and evaluation that will be got by the students, Thus, if teachers find that existing materials do not fulfill their students' need. They should develop teaching materials in order to meet the students' need because the teacher has a responsibility to facilitate students in learning process in the classroom. 
work, and providing feedback at appropriate instances to the students. Reading can help people to comprehend their environment. The teacher needs an appropriate and effective reading learning materials to help the students comprehend their environment effectively. The teacher has to design the learning materials carefully considering that learning materials are important to make the teaching learning process run well and to achieve the goal of the learning.

Beside the learning materials, the strategies or methods used by the teacher in students' learning activities are also have the significant effect for students' learning. Arends (2007:308) PBL is a student-centered instructional strategy in which students collaboratively solve problem and reflect on their experiences. Problem used in PBL are contextualize real-world problems and are typically a set of descriptions of phenomena or situations in need of explanations and resolution. They are often presented in textual format, sometimes with illustrations, pictures, videos, and simulations. Problem are sometimes classified as explanation problems, descriptive problems, or strategy problems based on their objectives.

In line with the processes, Brandon Goodman (2003: 27) says that the essence of problem-based learning consist of presenting students with aunthentic and meaningful problem situations that can serve as springboards for investigations and inquiry. In line with the processes, (Schmidt, 1983), overall, the learning process in PBL, is self-directed by students and is more problem centered then teacher centered.The role of teacher in Problem Based Learning is considerably different from the role of teachers in a convetional curriculum, not only because they have a different name: tutors, PBL tutors facilitate the students 
learning process by observing the students, stimulating discussion amongst team members, raising thought-provoking questions, encouraging collaborative.

Considering the problems above, the researcher plans to develop Problem based learning materials for grade ten of Vocational school. The reading materials developed based on students needs by using problem based learning. The reading materials are made by following the problem based learning steps by students are presented with a problem in a small group with a problem,students discuss the problem in a small group problem based lerning tutorial, students engage in independent study on their kearning issues outside, they come back to the problem based learning group, sharing information and working together on the problem, they present and discuss the problem, and the review what they have learn from working on the problem.

\section{REVIEW OF LITERATURE}

Reading is a mean of language learning, communication, and of sharing information and ideas. As all language, it is a complex interaction between the text and the reader that is shaped by the reader' prior knowledge, experiences, attitudes and language community that is situated culturally and socially.

In addition, reading is generally known as a receptive skill of language. Hameed (2009) emphasizes that it is not an exaggeration to say that reading is the most important skill among four well-known ones through which learners acquire most of their knowledge. 
Problem Based Learning (PBL) as an educational process that aims to help students see meaning in the academic material There are several definitions of PBL based on some litelatures. According to Arends (2007:308) Problem Based Learning is a student-centered instructional strategy in which students collaboratively solve problem and reflect on their experiences. Brandon Goodman (2003: 27) says that the essence of problem-based learning consist of presenting students with aunthentic and meaningful problem situations that can serve as springboards for investigations and inquiry. Following a period of self-study, they reconvene to discuss, share information, and synthesize answers to their quiries as a team, integrating their new knowledge in the context of the problem (Schmidt, 1983), overall, the learning process in PBL, is self-directed by students and is more problem centered then teacher centered.

The role of teacher in Problem Based Learning is considerably different from the role of teachers in a convetional curriculum, not only because they have a different name: tutors, PBL tutors facilitate the students learning process by observing the students, stimulating discussion amongst team members, raising thought-provoking questions, encouraging collaborative work, and providing feedback at appropriate instances to the students. 


\section{RESEARCH METHODOLOGY}

This study was conducted by using Reseach and Development (R\&D). Research and development (R\&D) is a development model in which the findings of research are used to design new product and procedures, which are sistematically field-tested, evaluated and refined until they meet specify criteria of effectiveness quality or similar standard. (Borg, Gall \& Gall, 2003:569). This study was conducted by following the six stages in R \& D. They were gathering information and data, analyzing data, designing new material, validating new material, revising new material, revised-developing new material.

The research place was at SMK Sinar Husni Medan which consists of 38 students of Electrical Engineering study program. The source of data was syllabus, existing materials, teachers’ interview and students’ questionnaire.

The data of research was collected by interview, questionnaire and documentation. Interview and questionnaire administer to gather information about students' needs, problems and interesting in learning English. The first, the syllabus and material were observed to analyze the basic competence, students' worksheet, and the book. The second, an interview was conducted to an English teacher to get information about students' problem which was faced in learning English especially reading, and also about the materials. The third, the questionnaire was conducted to the students in order to get information about students’ need in learning English. 
The flow chart of developing the materials

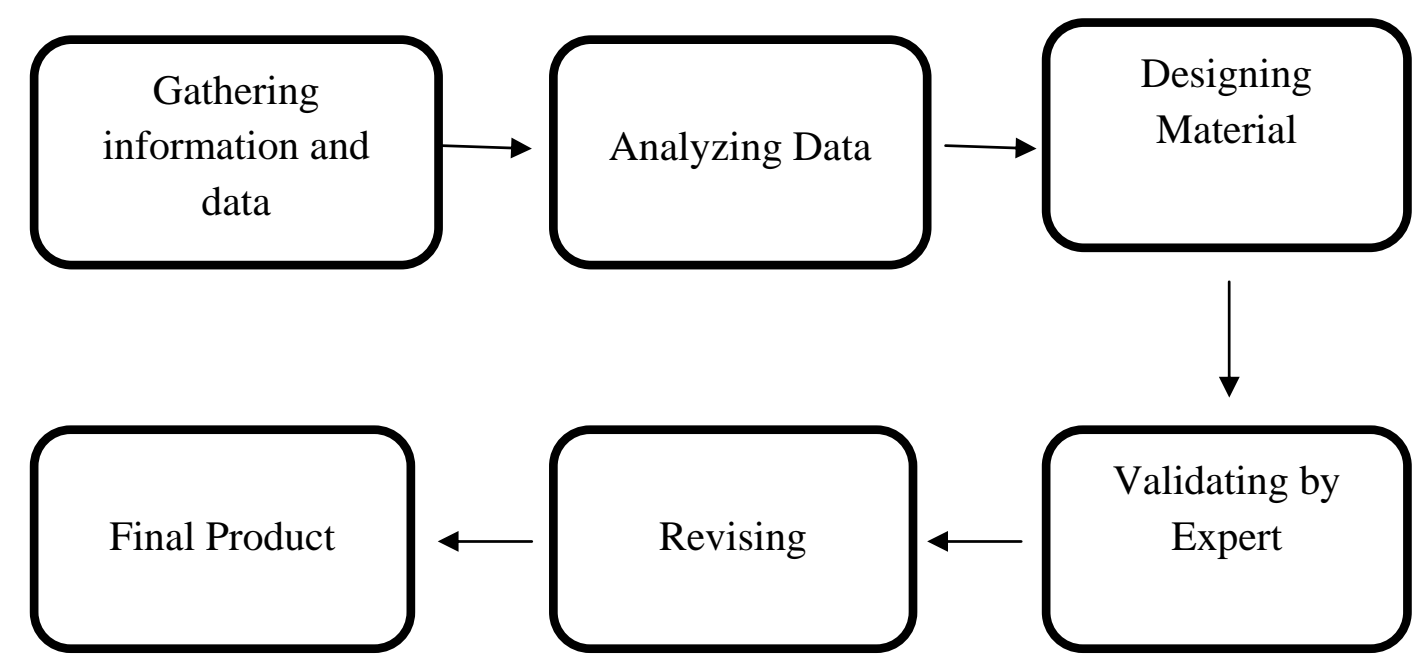

Figure 1.1 The flow chart of developing the materials

\section{RESEARCH FINDINGS}

The aim of this study was to develop appropriate English reading materials of descriptive text based on Contextual Teaching Learning for grade X students of Electrical Engineering at SMK Sinar Husni Medan. In order to identify the needs of students of Electrical Engineering program, the questionnaire was administered to the students and the interview was administered to the English teacher. There were 15 questions that were answered by the students. It was the target needs and learning needs of the students.

Target needs is what the learners need to do in the target situations. It was consisted the term of necessities, lacks, and wants. In term of necessities, most of the students demand to master in reading skill and the English materials were about office administration. The lacks, most of the students were weak in reading skill because they were lack of vocabulary. In term of wants, most of the students 
wanted English can help them to comprehend reading text and vocabulary related to office administration. Based on this result, it was decided to make a reading text related to Electrical context.

The next part is learning needs. The students' learning needs were found in the items which are categorized as input, procedure and setting. The need analysis result showed that the students prefered theme of the text which appropriate with the Electrical Engineering Program as the input of reading, in term procedure, answer the questions from the text was chosed as reading activity. Furthermore to improve their vocabulary, the students wanted the materials related term to their major. In term of setting the students preferred to do the task of reading into paired consisting of two people.

After the needs analysis had been conducted, the next step was formulating a course grid and wrote the first draft of the reading materials based on Contextual Teaching Material. The results of need analysis were used as a basic to develop the course grid. The reading materials contain of four texts, those are Remote Control, Air Conditioning, Printer, and Benjamin Franklin and fourteen task. Each task differ of 4 sections namely, WarmUp, Lets Start, Evaluation and Reflection. Those section were part of six principles of Contextual Teaching Learning.

The next step was expert judgment process. The materials were evaluated by two experts. The criteria for expert judgment were based on the BSNP standard (Contents, language use, methodology and layout). In the process of experts 
judgments, there are some mistake should be replace, such as grammatical, spelling, and the vocabularies. Therefore, to get the quality of the product, product was gave to the validator to be validated. The validators came from and English Lecturer from State University of Medan that was Prof Dr.Sumarsih,M.Pd., as the first validator and an English Teacher from SMK Sinar Husni Medan, Nurlaili Khaira Khalid, S.Pd., as the second validator. As the result from the first validator evaluation 5,17 or $92 \% \%$ and it was categorized as relevant. Beside that from the second validator evaluation also got 4.68 or $87,6 \%$ and it was categorized as relevant. Thus, the final draft or the developed English reading materials were valid and appropriate to be used as learning materials for grade $\mathrm{X}$ students Electrical Engineering program.

\section{CONCLUSION AND SUGGESTIONS}

\section{The Conclusion}

1. Based on the need analysis from the questionnaire and the interview, it was concluded that the students of office Administration program in Grade $\mathrm{X}$ at SMK Sinar Husni Medan need the appropriate English Reading materials particularly description of things in the Electrical. The English Reading material was developed in order to increase their knowledge about the general description of things in the office and learn new vocabulary. Then, students know about kinds of thing in the office which can support their job in the future.. 
2. The score of validation from the first validator was 5,17 or $92 \%$ and it was categorized as relevant and the score of validation from the second validator was also 4.4 or $87,6 \%$ and it was categorized as relevant. It means that, the materials were valid and appropriate to use as learning materials for students of Electrical Engineering program for Grade X at SMK Sinar Husni Medan.

\section{The Suggestions}

There are three suggestions, they are:

1. Teacher

Teachers should consider the students' needs in choosing the learning materials. The learning process can be successful if the teacher can give the materials related to the students' program and also the teacher can apply “English for Specific Purposes” approach to apply in teaching English for vocational high school students.

2. Students

Students can find the materials related to their study program from the internet and the other books, if the existing materials provided are not appropriate to Electrical Engineering program. So, the students can learn with the appropriate materials especially in English subject.

3. Other Researcher

Other researcher should find many references to support in developing reading materials. The questions in questionnaire should be considered to 
give the students' chance to deliver their wants in learning English specifically in Reading skill. 


\section{REFERENCES}

Cindy E.Hmelo and Dorothy H. Evensen. 2000. Problem Based Learning : A Research Perspective on learning Interactions

Gall, M.D., Joyce, P.G., Walter, R.G. 2003. Educational Research: An Introduction. United State of America: Pearson Education.

Hutchinson, T. \& Waters, A. (1987). English for Specific Purposes: A learningcentered approach. Cambridge: Cambridge University Press.

Richards, J.C \& Rodgers, T.S. 2001. Approaches and Methods in Language Teaching. Cambridge. Cambridge University Press.

Schwegler, Robert A. (2010). Patterns of Exposition 9th Ed. Boston: Pearson Education Inc

Dharma , 2014. Problem Based Learning : Critical and Creative Thingking of Students. Mengwi : SMA N 1 Air Putih.

Schmidt, 1983 . Problem Based Learning : Rationale and Description, Department of Educational development and research, the Netherlands 